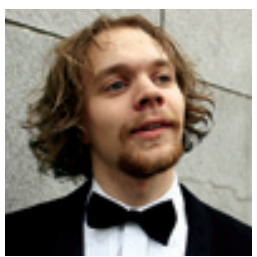

\title{
Medisin med det samme
}

\section{Offentlige sykehus i Norge er bedre enn sitt rykte. Men de private lege- kontorene er flinkere til å skrive ut medisiner.}

På den altfor store tv-en på det bittelille rommet vi leide på Upper East Side i New York i september, var det stadig tv-reklamer for medikamenter. Noen av dem virket, mildt sagt, spekulative. Blant annet så vi reklame for pillen Requip, som visstnok var medisin for noe de kalte «rastløse lår-syndrom». Alle disse reklamene sluttet med samme oppfordring: Fortell legen din hvilke medisiner du trenger! Det fikk meg til å tenke på komiker Bill Mahers kommentar til dette fenomenet, «er det ikke egentlig legen som bør fortelle DEG hvilke medisiner DU bør ta?»

I USA er de private legekontorene det nærmeste jeg kommer minnene om helsesøster på barneskolen. Da jeg var liten, fikk jeg godteri etter å ha vært på besøk der. Før var det altså kjærlighet på pinne, nå er det kjærlighet på pille. Jeg er et typisk barn av den gamle skolen. Jeg foretrekker allmennkringkaster framfor kommersiell tv, og jeg prøver som regel å benytte fastlegen og offentlige sykehus. Men i blant er det vanskelig å motstå de private legekontorene i Oslo, der de ligger på toppen av glorete kjøpesentre. Fastlegen stiller vanskelige spørsmål og skriver sjelden ut resepter hvis det ikke er høyst nødvendig. Selv gikk jeg inn til en norsk privatlege for å ta en rutinesjekk før en opptreden på en oljeplattform og nevnte samtidig at jeg var litt sliten på grunn av for mye arbeidspress. Jeg fikk to resepter i hånda. En for $\mathrm{B}_{12}$-sprøyter og en annen for Cipralex.

Disse besøkene hos privatleger gjorde at jeg ofte gikk rundt med litt dårlig samvittighet, på en måte følte jeg at jeg sviktet egne idealer. Og da jeg ble akutt matforgiftet $\mathrm{i}$ Ungarn i sommer og lå dehydrert $i$ to dager, ga to ambulansesjåfører meg valget mellom «det amerikanske» privatsykehuset i sentrum eller et offentlig sykehus i utkanten av Budapest. Jeg valgte å gå for Einar Gerhardsen-løsningen. Sjåføren stoppet utenfor en bygning som så ut som en nedlagt kaserne. To gamle damer i sandaler, som skulle vise seg å være resepsjonister på det offentlige sykehuset, kom gående ut. De kommuniserte hissig til kjæresten min og meg på verdensspråket ungarsk. Det var vanskelig å forstå, selv for min halvt ungarske kjæreste. Hun unnskyldte seg med at det er mange nye kraftuttrykk som er kommet til i det ungarske språket siden hun bodde der. Men i enden av en gangvei, $i$ et hus som ble skutt i stykker under den annen verdenskrig, lå det et sykehus. Der ble jeg lagt i en seng, med en intravenøs slange i kroppen. Vann hadde de ikke der, da jeg fikk vite at «det er en regel om at sånt skal man ha med selv»». Men jeg kunne gjerne forsyne meg med vann i springen i gangen, hvis jeg klarte å komme meg dit - med slangen og stativet.

Det var uutholdelig å ligge der. Det var 30 grader varmt, og nattsvermere med kropper på størrelse med bordtennisballer fløy rundt leselampa mi. Sykesøstrene som tilfeldigvis kom forbi og så dette, knuste krypene med håndflatene sine før de jobbet videre med sårene til folk. Legen, som het Laszlo, kom kun innom på en hastevisitt én gang hver dag - og snakket bare ungarsk. Jeg hadde ikke peiling på hva som feilet meg - eller hvor lenge jeg måtte bli der. Og dette var bare starten.

Om natten ryker den intravenøse slangen, og jeg begynner å striblø. Jeg prøver å ringe sykesøsteren, men tilkallingsalarmen virker ikke, så jeg må gå nedover korridoren med trillestativet, mens det renner en lang strøm med blod etter meg. Den mannlige pasienten på venteværelset som ser meg komme, løper rett ut døren - og mest sannsynlig råkjører han til «det amerikanske sykehuset». Når helsesøster endelig ser meg, banner hun og rister på hodet.

Neste dag våkner jeg opp av at en 80 år gammel krigsveteran med protese legger seg i nabosengen ved siden av. Han får også intravenøst, men om natten ryker også denne ledningen og mannen begynner å fossblø. Heller ikke denne gangen virker tilkallingsalarmen, så mens jeg sover prøver mannen iherdig å ta på seg protesen, samtidig som blodet hans sørger for at den gule, glorete tapeten på veggen blir tildelt en, for øvrig mer kledelig, rødfarge. Midt oppi denne kavingen løsner protesen hans fullstendig, noe som resulterer $i$ at han faller over meg og spruter magen min full av ungarsk blod. De kvinnelige sykepleierne strømmer endelig til og han roper «kurva, kurva» til dem - en ikke særlig pen ungarsk betegnelse, vanligvis brukt om kvinner med verdens eldste yrke.

Jeg synes folk klager for mye på norske leger. Jeg kommer ikke til å gjøre det. Ikke nå lenger. For sammenliknet med ungarske sykehus er de norske offentlige sykehusene som luksushotell å regne. Og selv om de private legekontorene i Norge tidvis nok er for slepphendte med resepter, er de i alle fall bedre enn i USA. Der er de jo like måteholdne når det kommer til medikamenter som Keith Richards i Rolling Stones.

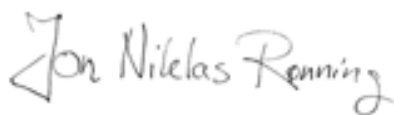

Håndrotsfraktur

Nefrogen systemisk fibrose

Pregabalin og misbrukspotensial
Karsinoid hjertesykdom

Epilepsi i Kina

Pasientkommunikasjon 